Model-Based Predictions of the Effects of Harvest Mortality on Population Size and Trend of Yellow-Billed Loons

Open-File Report 2009-1040 



\section{Model-Based Predictions of the Effects of Harvest Mortality on Population Size and Trend of Yellow-Billed Loons}

By Joel A. Schmutz

Open-File Report 2009-1040

U.S. Department of the Interior

U.S. Geological Survey 


\section{U.S. Department of the Interior \\ KEN SALAZAR, Secretary}

\section{U.S. Geological Survey \\ Suzette M. Kimball, Acting Director}

U.S. Geological Survey, Reston, Virginia: 2009

For more information on the USGS-the Federal source for science about the Earth, its natural and living resources, natural hazards, and the environment, visit http://www.usgs.gov or call 1-888-ASK-USGS.

For an overview of USGS information products, including maps, imagery, and publications, visit http://www.usgs.gov/pubprod

To order this and other USGS information products, visit http://store.usgs.gov

Suggested citation:

Schmutz, J.A., 2009, Model-based predictions of the effects of harvest mortality on population size and trend of Yellow-billed Loons: U.S. Geological Survey Open-File Report 2009-1040, 18 p.

Any use of trade, product, or firm names is for descriptive purposes only and does not imply endorsement by the U.S. Government.

Although this report is in the public domain, permission must be secured from the individual copyright owners to reproduce any copyrighted material contained within this report. 


\section{Contents}

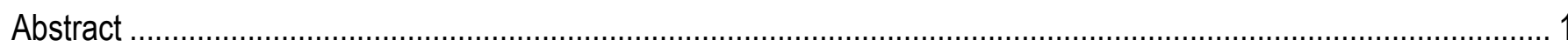

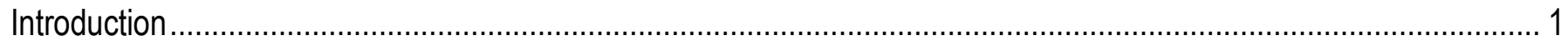

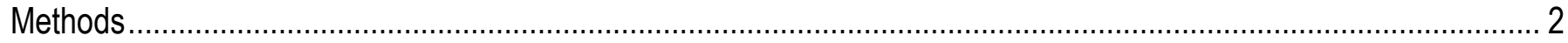

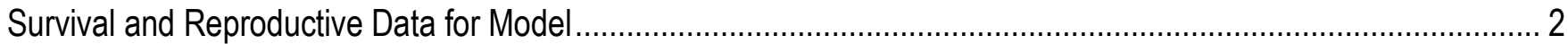

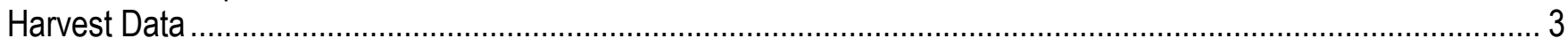

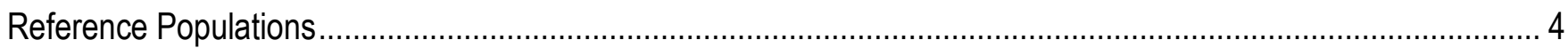

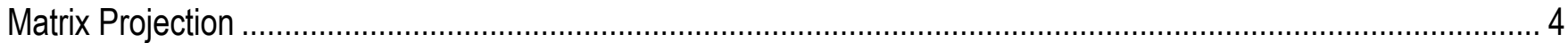

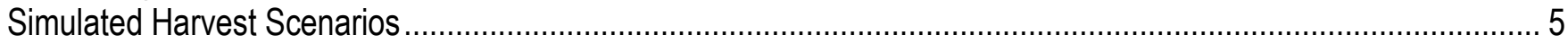

Results

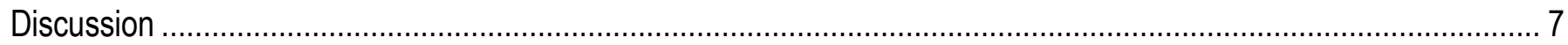

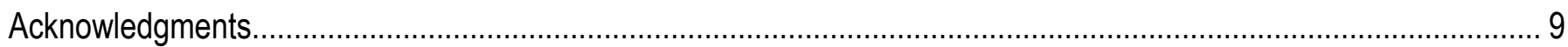

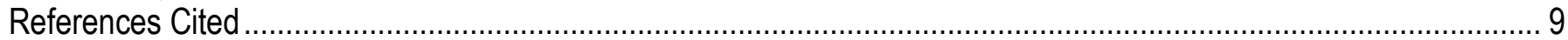

Appendix 1. SAS Code Used for Performing Matrix Projections to Model Effects of Harvest on

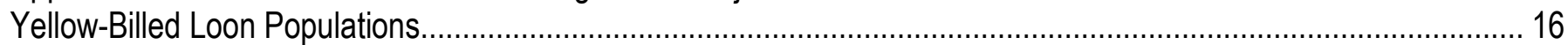

\section{Figures}

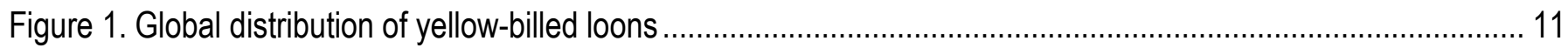

Figure 2. Matrix of demographic parameters used for projecting population size of yellow-billed loons ..................... 12

Figure 3. Harvest rate of yellow-billed loons for 12 scenarios ( 3 different initial harvest amounts multiplied by four different Reference Populations) 13

Figure 4. Fall migration of two yellow-billed loons marked in July 2003 with satellite transmitters.

\section{Table}

Table 1. Predictions of the effect of harvest on population size and trend of yellow-billed loons 15 
This page left intentionally blank 


\title{
Model-Based Predictions of the Effects of Harvest Mortality on Population Size and Trend of Yellow-Billed Loons
}

\author{
By Joel A. Schmutz
}

\begin{abstract}
Yellow-billed loons (Gavia adamsii) breed in low densities in northern tundra habitats in Alaska, Canada, and Russia. They migrate to coastal marine habitats at mid to high latitudes where they spend their winters. Harvest may occur throughout the annual cycle, but of particular concern are recent reports of harvest from the Bering Strait region, which lies between Alaska and Russia and is an area used by yellow-billed loons during migration. Annual harvest for this region was reported to be 317 , 45, and 1,077 during 2004, 2005, and 2007, respectively. I developed a population model to assess the effect of this reported harvest on population size and trend of yellow-billed loons. Because of the uncertainty regarding actual harvest and definition of the breeding population(s) affected by this harvest, I considered 25 different scenarios. Predicted trends across these 25 scenarios ranged from stability to rapid decline (24 percent per year) with halving of the population in 3 years. Through an assessment of literature and unpublished satellite tracking data, I suggest that the most likely of these 25 scenarios is one where the migrant population subjected to harvest in the Bering Strait includes individuals from breeding populations in Alaska (Arctic coastal plain and the Kotzebue region) and eastern Russia, and for which the magnitude of harvest varies among years and emulates the annual variation of reported harvest during 2004-07 (317, 45, and 1,077 yellow-billed loons). This scenario, which assumes no movement of Canadian breeders through the Bering Strait, predicts a 4.6 percent rate of annual population decline, which would halve the populations in 15 years. Although these model outputs reflect the best available information, confidence in these predictions and applicable scenarios would be greatly enhanced by more information on harvest, rates of survival and reproduction, and migratory pathways.
\end{abstract}

\section{Introduction}

Of the world's five loon species (genus Gavia), the yellow-billed loon (G. adamsii) is the rarest and most northerly distributed. Its breeding habitats are large lakes in tundra ecosystems primarily north of the Arctic Circle (fig. 1). Non-breeding habitats are principally coastal marine waters at mid to high latitudes. In the United States there are two breeding areas, both in northern Alaska - the Arctic coastal plain region north of the Brooks Range and the region surrounding Kotzebue Sound in northwest Alaska, primarily the northern Seward Peninsula. A series of aerial 
surveys in these areas estimated the total Alaska breeding population size as 3,844, which include 3,369 for the Arctic coastal plain, as estimated by Earnst and others (2005) and an additional 475 from the Kotzebue Sound region, as summarized by the U.S. Fish and Wildlife Service (USFWS) Region 7. Yellow-billed loons breed in north-central Canada and in northern Russia, but a lack of surveys in these regions leads to uncertain estimates of abundance. Through a detailed review of all available data and considerations of the distribution of relevant habitats, USFWS Region 7 estimated that there are 8,000 to 20,000 yellow-billed loons in Canadian breeding habitats. Similarly, in evaluating the sparse information for Russia, USFWS Region 7 estimated 2,000 to 5,000 for the Chukotka region of eastern Russia, and 3,000 for areas in western Russia, including the Taymyr Peninsula region. Combining these regional estimates, USFWS Region 7 estimated the global population of yellow-billed loons on breeding area habitats to be a minimum of 16,000 and a maximum of 32,000.

In March 2004, the USFWS was petitioned to list the yellow-billed loon as threatened or endangered under the Endangered Species Act. The rationale offered in that petition (Bosman, 2004) was the species' relatively low abundance, restricted geographic distribution, and that the population was exposed to a range of threats. One threat is subsistence harvest, including hunting and incidental bycatch in fishing nets. Recent reports documenting apparent harvest by villages in the Bering Strait region of the United States (fig. 1) have heightened concern about such harvest (Naves, 2008,; U.S. Fish and Wildlife Service and others, 2008). Consequently, I conducted a quantitative evaluation of how different levels of harvest may impact yellow-billed loons at the population level. The primary objective of this report is to develop a population model for the species and examine how sensitive future population size and trend are to mortality rates imposed through harvest.

\section{Methods}

My general modeling strategy was to synthesize the best available information on demographic parameters and summarize these into a matrix projection model. I then conducted a sensitivity analysis wherein survival rates are altered, as impacted by a series of simulated harvest levels, to quantify their impact on population trends and abundance. I simulated several different magnitudes of harvest mortality to emulate the magnitudes reported by Naves (2008) and U.S. Fish and Wildlife Service and others (2008). Further, to reflect the uncertainty about the source and size of breeding population(s) affected by this harvest during migration, I used four different perspectives on breeding population size and origin, ranging from just Alaska to a maximum view of the global population. Importantly, this modeling approach begins with a hypothetical population at stability, and it then simulates varying levels of harvest which deterministically requires a population to decline at some rate, assuming that harvest does not incite a compensatory demographic response.

\section{Survival and Reproductive Data for Model}

Extremely few yellow-billed loons have been banded. Consequently, survival rates and age at first breeding are unknown for this species. Such data do exist, however, for common loons (G. immer), a species very similar to yellow-billed loons in size and appearance (except with a dark bill) and with an adjacent and more southerly breeding distribution in the boreal and northern hardwood forests. I thus began construction of a matrix model by using annual survival 
estimates of common loons of $0.71,0.80$, and 0.91 , which respectively represent survival of fledglings, 1-year olds, and all loons older than 1-year old (Mitro and others, 2008). I also constructed the matrix model assuming that no yellow-billed loons begin breeding before 6 years of age and that all loons are territorial by age 6 , based on mean age at first breeding for common loons (Evers, 2006).

The few studies of yellow-billed loons on their breeding grounds have primarily occurred on the Colville River Delta on the eastern edge of their distribution in Alaska's Arctic coastal plain. For 13 years during 1993-2007, employees of ABR Inc. assessed productivity of yellowbilled loons by conducting intensive aerial (primarily helicopter) surveys during nesting and during late brood rearing (ABR Inc., unpub. data). An annual mean of 40 territorial pairs were observed, and the mean percent of such pairs that raised chicks into late summer (about 6 weeks of age) was 28.5 percent. By multiplying the proportion of pairs with chicks by 1.172 (the mean number of chicks per brood), I estimated the mean number of young yellow-billed loons produced per territorial pair.

Synthesizing the above survival and reproductive rates into a matrix model yields an estimate of population growth (the dominant eigenvalue of the matrix; Caswell, 2001; Morris and Doak, 2004) of 0.9806. I then increased the three age-specific annual survival rates by a common proportion (1.98 percent) to achieve a growth rate of 1.0, representing population stability in the absence of any human harvest. The rationale for this adjustment was two-fold. First, from the perspective of comparative evolution of life histories (Stearns, 1992), the average survival rates of yellow-billed loons might be slightly higher than for common loons, as the longterm mean productivity rate of common loons (Evers, 2006) appears to be higher than the above 13-year record for yellow-billed loons. Second, the precise values initially used for these survival rates are not important. Rather, my purpose is to contrast the degree to which population growth is affected by simulating varying levels of harvest. Measuring percent changes from stability is thus a convenient and intuitive way to represent such results.

\section{Harvest Data}

In Alaska, harvest by indigenous people in rural regions is monitored by a subsistence harvest survey program. Annual reports from this survey program for 2004, 2005, and 2007 are now available (Naves, 2008; U.S. Fish and Wildlife and others, 2008). This survey is conducted by contracted local residents who are responsible for interviewing a random set of households in each village. At each selected household, the interviewer queries residents as to how many birds of which species they had harvested in the most recent harvest periods. They also provide pictorial guides of species to help residents accurately identify harvested species. Numbers reported by sampled households are then extrapolated to all households to estimate region-wide harvest (Naves, 2008). The greatest reported harvest of yellow-billed loons is from the Bering Strait region, which includes the villages of Gambell and Savoonga (both on St. Lawrence Island) and the village on Little Diomede Island (fig. 1). The estimated annual harvest of yellowbilled loons from the Bering Strait region for the 3 above years was 307, 45, and 1,077. The effect of these three harvest levels were simulated in the projections of future population size (see section, "Simulated Harvest Scenarios”). 


\section{Reference Populations}

The Bering Strait region commonly is used by yellow-billed loons during migration but not for breeding. Thus, it is unclear what breeding populations may be impacted by harvest in this region. The proximity of breeding loons in the Kotzebue Sound region suggests they would use the Bering Strait, and this supposition is supported by satellite tracking data from 10 yellowbilled loons marked there, all of which migrated through the Bering Strait. From the larger population breeding on Alaska's Arctic coastal plain, satellite tracking data from yellow-billed loons marked there in 3 different years indicated that the annual percentage of these loons that migrated through the Bering Strait region ranged from 0 to 80 percent, with the remainder overflying the Chukotskiy Peninsula (Schmutz, unpub. data, 2008). Thus, all of Alaska's yellowbilled loons are likely subject to harvest from the Bering Strait region, although the magnitude may vary from year to year in relation to migration patterns. Yellow-billed loons breeding in Canada and Russia also may migrate through the Bering Strait (not yet known, and addressed in section, "Discussion"), and thus in my simulation of harvest effects, I used four different starting, or reference, populations: (1) Alaska only, (2) Alaska plus those in the Chukotka region of eastern Russia, (3) a minimum estimate of the global population, and (4) a maximum estimate of the global population. The starting size for each of these four reference populations used in these matrix model analyses was based on the USFWS review of all available population information (see above).

For populations where individuals delay reproduction until a certain age, breeding populations may not fully represent total population size. The USFWS review of population sizes was all relative to terrestrial breeding habitats, and 1- and 2-year old yellow-billed loons may be at sea throughout the year. For common loons, known-age birds are not seen on breeding areas until they are 3-years old (Evers, 2006). Accordingly, the breeding population size estimates need to be adjusted to account for the subadult birds that are not present on breeding areas. I used the initial starting matrix model of survival and reproductive rates that predicted population stability, and from that matrix, I estimated that 14.7 percent of all yellow-billed loons of a given population are 1- or 2-year old birds (the dominant right eigenvector of the matrix; Caswell, 2001; Morris and Doak, 2004). I adjusted the reference population size accordingly.

\section{Matrix Projection}

I constructed the matrix model in the form of a "pre-breeding census" (Caswell, 2001) because annual estimates of population abundance and distribution are derived from breeding areas just before any young are hatched. This matrix of survival and reproductive rates has six columns reflecting six age classes: 1, 2, 3, 4, 5, and 6 years or older (fig. 2). The first row represents fecundity rates and the first five values in this row are 0 because this model assumes no breeding by birds younger than 6 years. The fecundity value in column 6 is the product of the mean productivity rate referred to above (ABR Inc. unpub. data, 2007) and the year-long survival of fledgling common loons (Mitro and others, 2008), with the aforementioned adjustment to achieve population stability. Non-zero values in the remaining rows reflect annual survival rates of the specific age-classes.

I then projected the matrix forward through time to simulate how the population size would change. Because I considered six Harvest Scenarios (see section, "Simulated Harvest Scenarios) for each of the four Reference Populations, I executed 24 matrix projections. All 
projections predicted declining populations because I started with a stable population and then imposed simulated harvest that is assumed to be additive (rather than compensatory) to natural mortality. Natural mortality is assumed to be constant across all scenarios, the rate being 1 minus the rate survival rates shown in figure 2. I executed these projections long enough to predict the population size after three generations and to identify in what year population size decreased below 50 percent of its starting value. A generation is defined as the mean age of parents (Stearns, 1992) and is estimated to be 18 years for yellow-billed loons, as calculated from the matrix in figure 2.

During each matrix projection, I recalculated age structure each year just after breeding because some of the newly fledged young are likely part of this harvest from the Bering Strait that occurs principally during migration. Such calculation is most important for the harvest scenarios where harvest is not equally distributed among age classes. Matrix projections were done using SAS software (SAS Institute, 1990), and the full code is shown as appendix 1.

\section{Simulated Harvest Scenarios}

For all harvest scenarios and analyses in this report, I have assumed that harvest is additive, rather than compensatory, to other sources of mortality. Compensatory behavior that may partially mitigate the population effect of harvest could hypothetically occur if harvest removed adult breeders, breeding habitat was limited, and the removal of older adults allowed younger birds to then breed at an earlier age then they would otherwise have done. There are no data to address such compensatory behavior for yellow-billed loons. For common loons, there are some indications this may occur (D. Evers, Biodiversity Research Institute, oral commun., 2009), but the frequency and conditions of such behavioral and population response have not been quantified.

Six harvest scenarios were considered. One scenario began with an annual harvest of 45 yellow-billed loons (one of the amounts of year-long harvest in the Bering Strait), which was proportionally distributed among all age classes. Dividing 45 by the initial population size provides a mortality rate from harvest, and I then kept this rate constant throughout the projection. Thus, in a declining population, a progressively smaller number of individual birds were simulated to be harvested, but the rate of harvest mortality was nonetheless constant. Second and third scenarios were structured similarly except with an initial harvest of 317 and 1,077 yellow-billed loons. A fourth scenario varied the mortality rates implied by 45,317 , or 1,077 birds initially harvested from the starting population. After each year of the matrix projection, the mortality rate rotated so that each of these three mortality rates contributed equally to the observed result and the simulation reflected annual variability in harvest of the magnitude described in subsistence harvest reports (see table 1). In all four of these scenarios, the population was stable without harvest, and when harvest was simulated it was distributed proportionately among age classes. Thus, mortality rate here functions as a rate of population reduction, where mortality rate due to harvest $=1-$ the population growth rate, and thus also equals the rate of population decline (fig. 3).

Unlike the previous four scenarios, the fifth and six scenarios were ones where harvest was not allocated proportionally among all age classes. In the fifth scenario, all harvest was allocated to newly fledged loons, 1-year old loons, and 2-year old loons, with the harvest among these three classes proportionally distributed. The rationale for this scenario is that these cohorts 
are the ones that (a) likely remain at-sea year round without necessarily returning to breeding areas and thus might spend disproportionately more time near the Bering Strait, (b) may be more naïve and thus more readily harvested, or (c) for juveniles, may be more readily confused with common loons (North, 1994), which are reported harvested in larger numbers in this region than yellow-billed loons (Naves, 2008). The sixth harvest scenario is the converse of the fifth in that all harvest is allocated to those loons age 3 or older, with the harvest among these older age classes distributed proportionately. The rationale for this scenario again reflects the uncertainty about where young loons spend their lives. If all yellow-billed loons younger than 3 years fail to migrate through the Bering Strait, then all reported harvest must be on these older age classes. The above six scenarios, combined with four Reference Populations, yields 24 population projections. In these fifth and sixth scenarios, harvest is not occurring on all age classes, and thus the rate of mortality due to harvest can not be equated to the rate of population decline. I executed one additional projection, which used Alaska as the Reference Population and then identified the harvest level that would produce the population trend currently observed in northern Alaska from annual aerial surveys (0.9886; Mallek and others, 2007).

For all these harvest scenarios, I am imposing a harvest rate that reduces the overall survival rate and thus depresses the population by some degree. Thus, in effect, I am addressing what happens to a population when mortality due to harvest is increased from whatever it has been.

The projection model I used was deterministic, rather than stochastic, meaning that it assumes that the various survival and reproductive rates are constant over time (other than the systematic variability imposed by the harvest rotation scenario). Of course, such constancy in survival and reproductive rates is unrealistic. Incorporation of empirical data regarding variation in reproductive rates is possible in future modeling efforts, given the time series of information from the Colville River Delta. Variation in survival is unknown due to sparse data. Variability in survival and reproductive rates is important to consider because heightened variation tends to depress population growth rates (Schmutz, 2009). Thus, with respect to variability in real vital rates, this deterministic modeling effort may slightly overestimate population viability of yellowbilled loons.

\section{Results}

From the perspective that all harvest is from the Alaska reference population, the annual mortality rate attributed to an initial harvest of 52 yellow-billed loons was sufficient to change the population growth rate $(\lambda)$ from stable to declining 1.14 percent per year $(\lambda=0.9886$; table 1 ). This growth rate equals the point estimate of the currently observed trend estimate for yellowbilled loons occurring on Alaska's Arctic coastal plain. At this rate of decline, the population will be reduced to less than one-half its former level in 61 years.

Minimum and maximum potential impacts of harvest on population trend of yellowbilled loons are portrayed by the 12 scenarios in table 1 that consider either 45, 317, or 1,077 loons initially harvested for each of the four reference populations. These scenarios vary from near stability to precipitous decline. With a harvest rate equal to that in the most recent subsistence harvest report (1,077; Naves, 2008), the population declined by 24 percent per year, halving the population in 3 years, when using Alaska as the reference population. Using this same value of 1,077 harvest but with the maximum global reference population, population 
decline was much slower, halving in 24 years. Projecting the model with a rotating harvest to reflect the three different harvest amounts reported this decade resulted in a population halving in 6 to 54 years, depending on the reference population. If all harvest occurs on just older birds, the population trend is only slightly depressed as compared to harvest being equally distributed among all age classes. This result is because there are few age 2 or younger birds in the population at any one time.

\section{Discussion}

The 25 scenarios of how yellow-billed loon populations may respond to harvest in the Bering Strait region range from almost no population effect to precipitous decline that will virtually extirpate the Alaska population within a few generations. Not all these scenarios are equally likely. I suspect that the distribution of yellow-billed loons that breed in Russia is similar to that for Steller's eiders (Polysticta stelleri), a species similar to yellow-billed loons in largescale ecological distribution and whose links between breeding and wintering areas have been identified through banding and satellite telemetry. Steller's eiders from the Taymyr Peninsula of Russia and westward during summer were linked to wintering areas in the northeast Atlantic in nearshore waters of Scandinavia (Petersen and others, 2006). In contrast, summering Steller's eiders east of the Taymyr Peninsula were linked to wintering areas in the north Pacific, along the Alaska Peninsula (Dau and others, 2000). Although there are no comparable banding or satellite tracking data for Russian-breeding yellow-billed loons, there are some observational parallels. Yellow-billed loons winter in the northeast Atlantic, for instance, in and near North Sea waters (Scott and Shaw, 2008). The breeding origin of these birds is unknown, but the Taimyr region of Russia is the closest Eurasian breeding area. Yellow-billed loons in north-central Canada are approximately equidistant from the North Sea as those breeding in the Taymyr Peninsula. However, a direct migration path between Canada and the northeast Atlantic waters would go over Greenland and over or near Iceland. Ornithologists in Iceland have not witnessed any migration of yellow-billed loons there (A. Petersen, Icelandic Institute of Natural History, oral commun., 2005). Regardless of which of these two breeding areas (western Russia vs. Canada) contribute to yellow-billed loons wintering in the northeast Atlantic, these loons most assuredly do not migrate through the Bering Strait.

Similar to the above discussion for Russia, there also is a lack of banding or tracking data for yellow-billed loons breeding in Canada. North (1993) summarized all available anecdotal information on observations of yellow-billed loons in North America and postulated that most yellow-billed loons wintering in nearshore waters of southern Alaska and British Columbia breed in Canada and likely migrate over-land. This inference was based primarily on a series of sightings of yellow-billed loons during migration near large lakes of northern Canada. For Canadian breeding birds to migrate coastally to southern Alaska waters, and thus through the Bering Strait, would necessitate a migration distance (about 4,400 km) about twice that of the overland route proposed by North (1993). Reliable inference about migration paths of Canadian breeding yellow-billed loons is not yet available. At present, I conclude that some portion of this population does migrate overland. Accordingly, I believe that the Alaska plus Chukotka reference population is the most plausible for considering the impacts of harvest occurring in the Bering Strait region. 
I considered four different magnitudes of harvest (starting values of 45, 317, 1,077, or a rotation among these three). The lack of a long-term, reliable harvest database hinders our ability to know what harvest has truly occurred. The large inter-annual variation in reported harvest for the Bering Strait region may reflect a reality of inter-annual variability in harvest opportunity, as indicated by satellite tracking data. I marked 5, 7, and 8 adult yellow-billed loons on Alaska's Arctic coastal plain with satellite transmitters in 2002, 2003, and 2008, respectively, and I observed large inter-annual differences in migration patterns. In 2002, 80 percent (4 of 5) of loons migrated through the Bering Strait, with most pausing for up to a week during fall migration in waters near St. Lawrence Island. This occurred in late September and early October, which corresponds chronologically to shore-based observations of Lehman (2005). The longest time periods that satellite marked loons resided in the Bering Strait were during fall migration, which also corresponded to the peak time of reported harvest (Naves, 2008). In 2003, 33 percent (2 of 6; the seventh died before migration) of marked loons migrated through the Bering Strait, and in 2008 no birds went through this region. All birds that failed to migrate in fall through the Bering Strait instead left northwest Alaska waters near Cape Lisburne and migrated towards Kolyuchinskaya Bay on the north coast of the Chukotskiy Peninusla (fig. 4). From there, they crossed over the Chukotskiy Peninsula to Anadyrskiy Bay and migrated southwest along the Russian coastline. The migration paths of all these marked yellow-billed loons converged southward of Anadyrskiy Bay, and the latter route over the Chukotskiy Peninsula is the more direct, shorter route. Whether or not these data reflect real inter-annual variation versus individual variation in migration is unknown. Further, hypotheses about the ecological causes for this variation in migration routes are presently quite speculative. Nonetheless, the reality of this observed variation leads me to believe that the most plausible harvest scenario is the one that annually varies harvest among starting values of 45,317 , and 1,077 loons.

I emphasize that this analysis addresses reported harvest for the Bering Strait region only. For the same year in which 1,077 yellow-billed loons were reported for the Bering Strait, there also were 84 yellow-billed loons reported as harvested from Alaska's Arctic coastal plain. There is no available information on what harvest may be occurring on this population while it migrates and winters in Russia and areas near the Korean peninsula and northern Japan.

From my discussion above, I consider the rotating harvest scenario in relation to the Alaska plus Chukotka reference population as the best representation (among those considered) of the real demographic situation experienced by yellow-billed loons in the Bering Strait region. From this perspective, the model results in table 1 predict $\lambda=0.9538$, with a halving of the population within 15 years. This value for $\lambda$ is just below the confidence limits of the current trend estimate derived from aerial survey data (USFWS Region 7), although this observed trend is only for northern Alaska yellow-billed loons and not for the whole Alaska plus Chukotka population. From this analysis, it appears that the viability of yellow-billed loon populations may be at risk due to harvest. However, one must recognize the uncertainty surrounding estimates of harvest, population size, and the underlying survival and reproductive rates in the model. Ideally, there would be more information about annual variation in harvest and reliability in reporting of harvest. Satellite tracking data from breeding populations in Canada and Russia also would greatly facilitate ascribing harvest during migration to source breeding populations. And finally, species and population specific information on survival and reproductive rates, and the potential for behavioral and demographic compensation for harvest mortality, would enable a more robust starting point for model projections. 


\section{Acknowledgments}

I am thankful to ABR Inc. and ConocoPhillips Inc. Alaska for availability and use of their longterm data on productivity of yellow-billed loons in the Colville Delta area. In particular, I thank R. Johnson, D. Nigro, C. Rea, and A. Wildman. U.S. Fish and Wildlife Service, Division of Migratory Bird Management Region 7, financially supported this modeling work. Constructive reviews of this report were offered by P. Flint, J. Schmidt, and T. Swem.

\section{References Cited}

Bosman, C., 2004, Petition to list the yellow-billed loon, Gavia adamsii, as an endangered or threatened species under the Endangered Species Act: Center for Biological Diversity, 75 p.

Caswell, H., 2001, Matrix population models: construction, analysis, and interpretation: $2^{\text {nd }}$ ed., Sinauer Associates, Sunderland, Massachusetts, USA.

Dau, C.P., Flint, P.L., and Petersen M.R., 2000, Distribution of recoveries of Steller's eiders banded on the lower Alaska Peninsula, Alaska: Journal of Field Ornithology, v. 71, p. 541548.

Earnst, S.L., Stehn, R.A., Platte, R.M., Larned, W.W., and Mallek, E.J., 2005, Population size and trend of yellow-billed loons in northern Alaska: Condor, v. 107, p. 289-304.

Evers, D.C., 2006, Status assessment and conservation plan for the common loon in North America: U.S. Fish and Wildlife Service, Hadley, Massachusetts, USA.

Lehman. P., 2005, Fall bird migration at Gambell, St. Lawrence Island, Alaska: Western Birds, v. 36, p. 2-55.

Mallek, E.J., Platte, R., and Stehn, R., 2007, Aerial breeding pair surveys of the Arctic coastal plain of Alaska: U.S. Fish and Wildlife Service, Anchorage, Alaska, USA.

Mitro, M.G., Evers, D.C., Meyer, M.W., and Piper, W.H., 2008, Common loon survival rates and mercury in New England and Wisconsin: Journal of Wildlife Management, v. 72, p. 665663.

Morris, W.F., and Doak, D.F., 2004, Quantitative conservation biology: theory and practice of population viability analysis: Sinauer Associates, Sunderland, Massachusetts, USA.

Naves, L., 2008, Alaska Migratory Bird Co-Management Council, Subsistence Harvest Survey, 2007 Preliminary Results: Alaska Department of Fish and Game, Division of Subsistence, Anchorage, Alaska, USA, 30 p.

North, M.R., 1993, Distribution and migration of yellow-billed loons in North America:. Bird Populations, v. 1, p. 36-49.

North, M.R., 1994, Yellow-billed loon (Gavia adamsii), The Birds of North America Online (A. Poole, Ed.). Ithaca: Cornell Lab of Ornithology; Retrieved from the Birds of North America Online: http://bna.birds.cornell.edu/bna/species/121.

Petersen, M.R., Bustnes, J.O., and Systad, G.H., 2006, Breeding and moulting locations and migration patterns of the Atlantic population of Steller's eiders as determined from satellite telemetry: Journal of Avian Biology, v. 37, p. 58-68.

SAS Institute, 1990, SAS Language: Reference, Version 6: SAS Institute, Cary, North Carolina, USA. 
Schmutz, J.A., 2009, Stochastic variation in avian survival rates: life-history predictions, population consequences, and the potential responses to human perturbations and climate change: Environmental and Ecological Statistics, v. 16, p. 441-461.

Scott, M.S., and Shaw, K.D., 2008, The status of white-billed diver in northwest Scotland: British Birds, v. 101, p. 241-248.

Stearns, S.C., 1992, The evolution of life histories: Oxford University Press, Oxford, United Kingdom.

U.S. Fish and Wildlife Service, Alaska Department of Fish and Game, and the Alaska Migratory Bird Co-management Council 2008, Migratory Bird Subsistence Harvest in Alaska, 20042006: Interim Report, Anchorage, Alaska, U.S.A. 


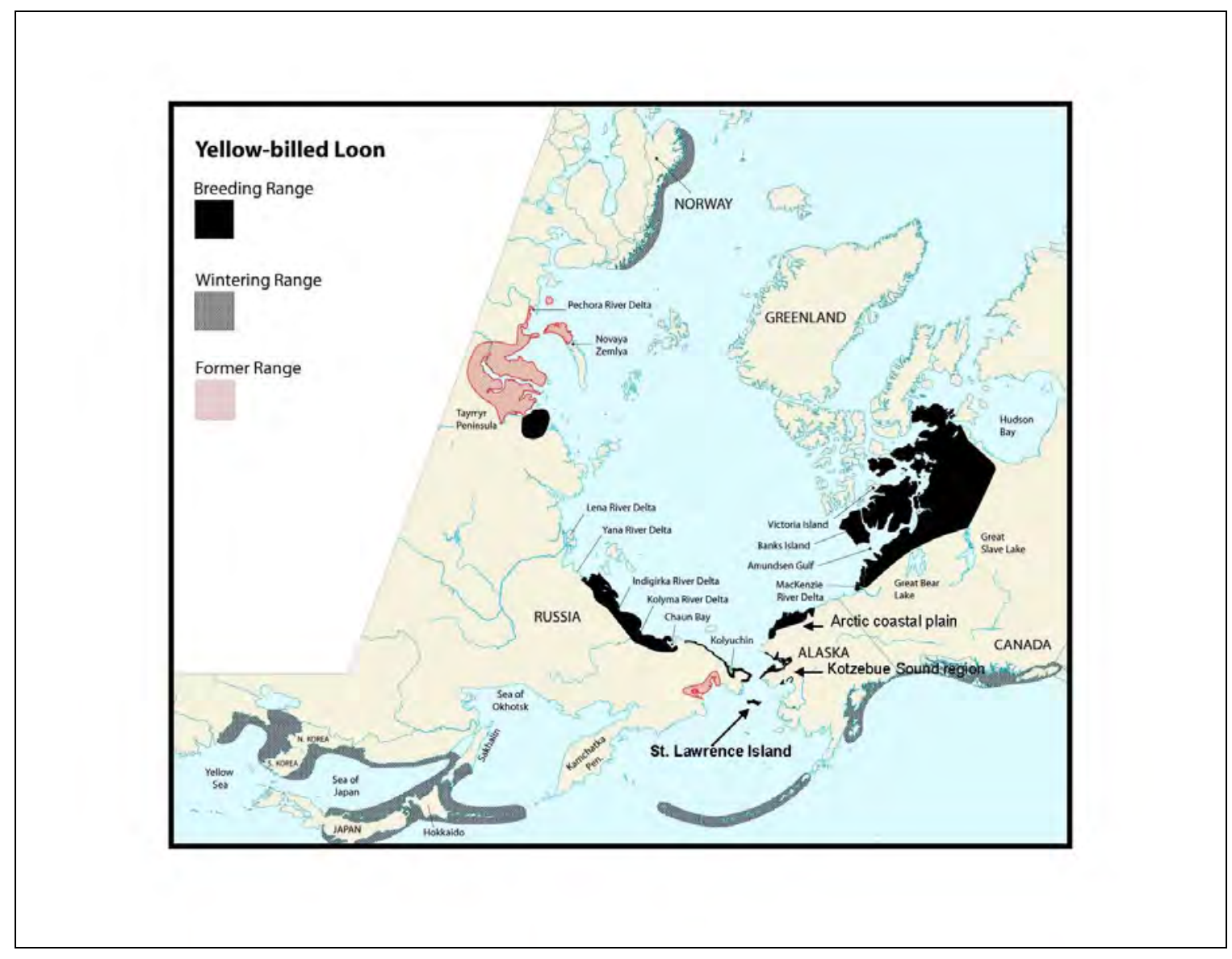

Figure 1. Global distribution of yellow-billed loons. 


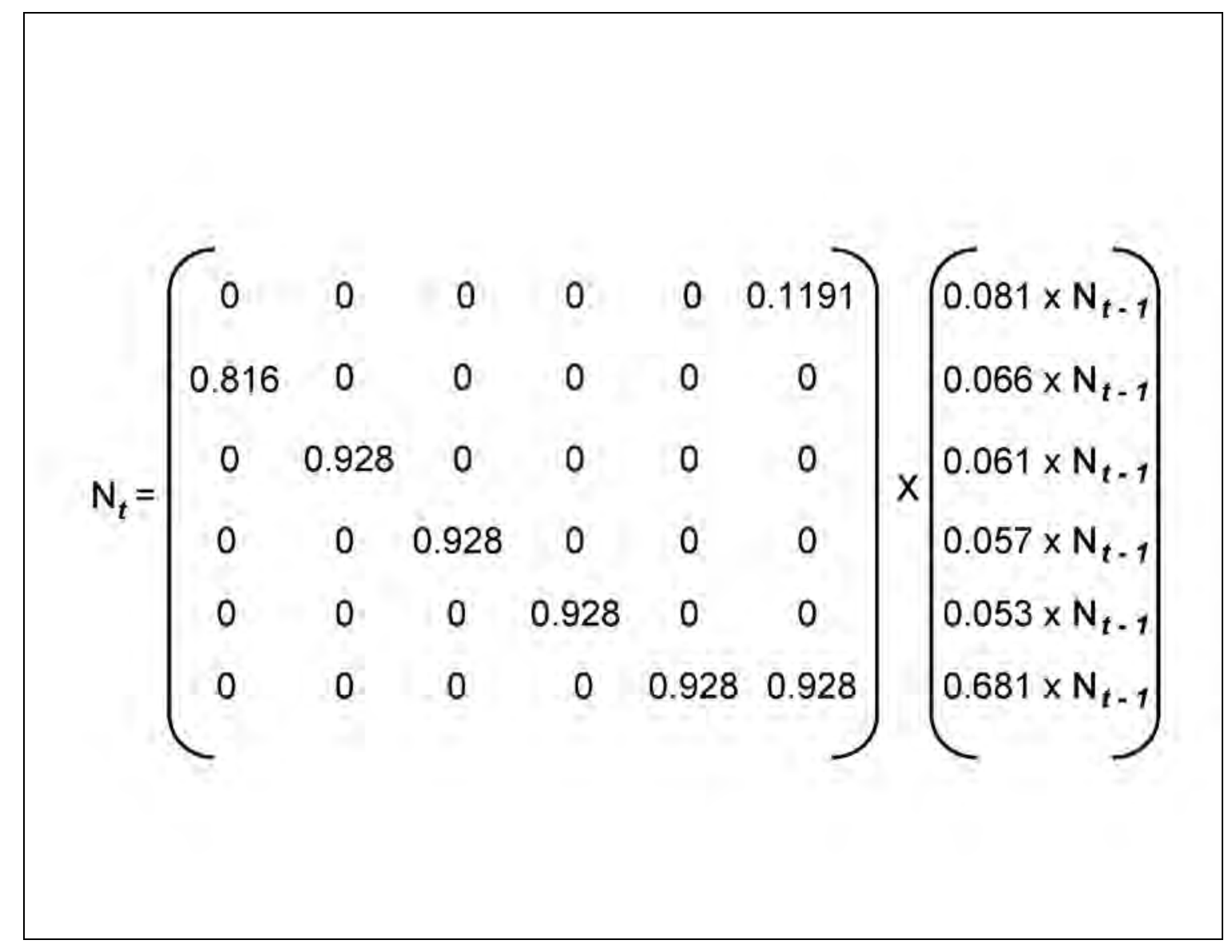

Figure 2. Matrix of demographic parameters used for projecting population size of yellow-billed loons. The right matrix, or scalar, represents the number of loons in age classes 1 to 6 , as calculated by the proportion in each class multiplied by the total population size, $\mathrm{N}$, at time $\mathrm{t}-1$. In left matrix, the upper right value is the fecundity of age 6 loons. Non-zero values in rows 2 to 6 represent age-specific annual survival rates, with row 2 representing 1 -year old loons. Derivations of the values to input to this matrix are discussed in the section, "Methods." 


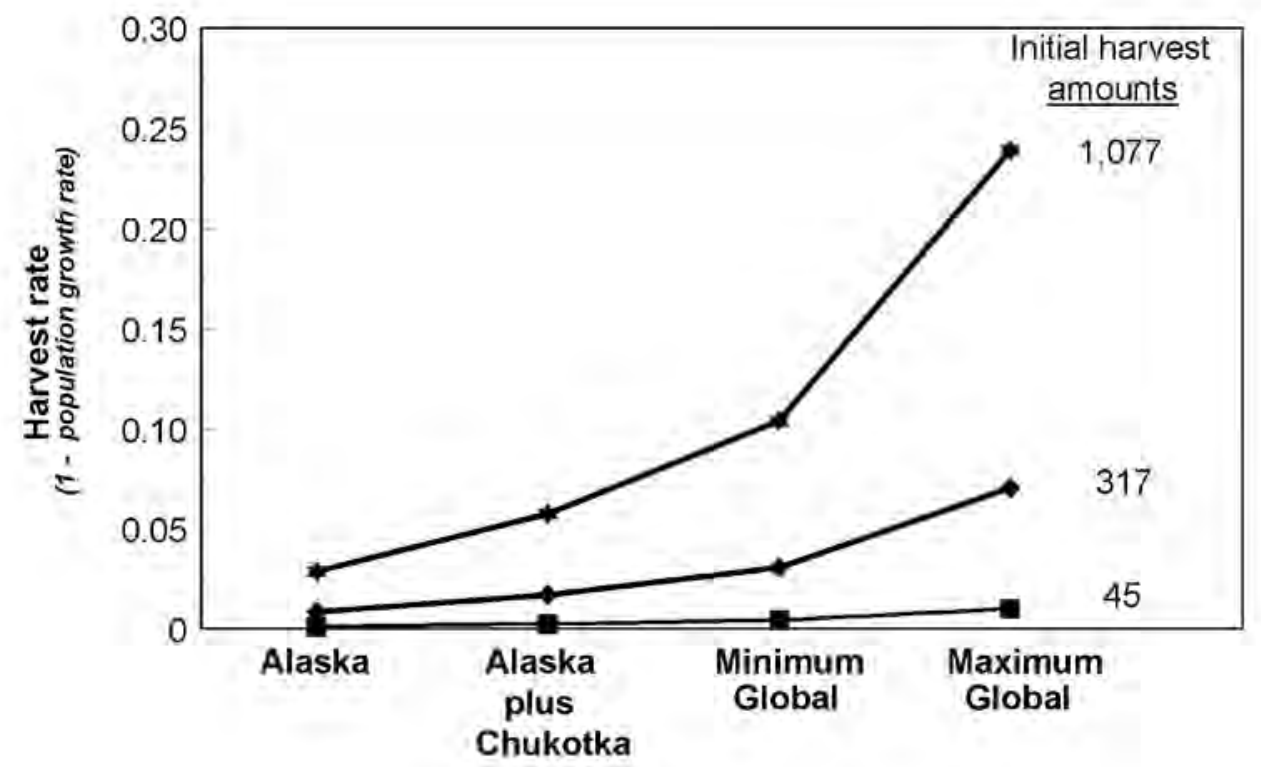

Figure 3. Harvest rate of yellow-billed loons for 12 scenarios ( 3 different initial harvest amounts multiplied by four different Reference Populations). Harvest rate represents the mortality rate due to harvest, assuming harvest does not incite any compensatory demographic response, and is calculated as the initial harvest amount divided by population size. In each of these scenarios, harvest is allocated to all age classes, including juveniles, in proportion to their availability in the population. Thus, harvest rate is equivalent to $1-\lambda$, which equals the rate of annual population decline. 


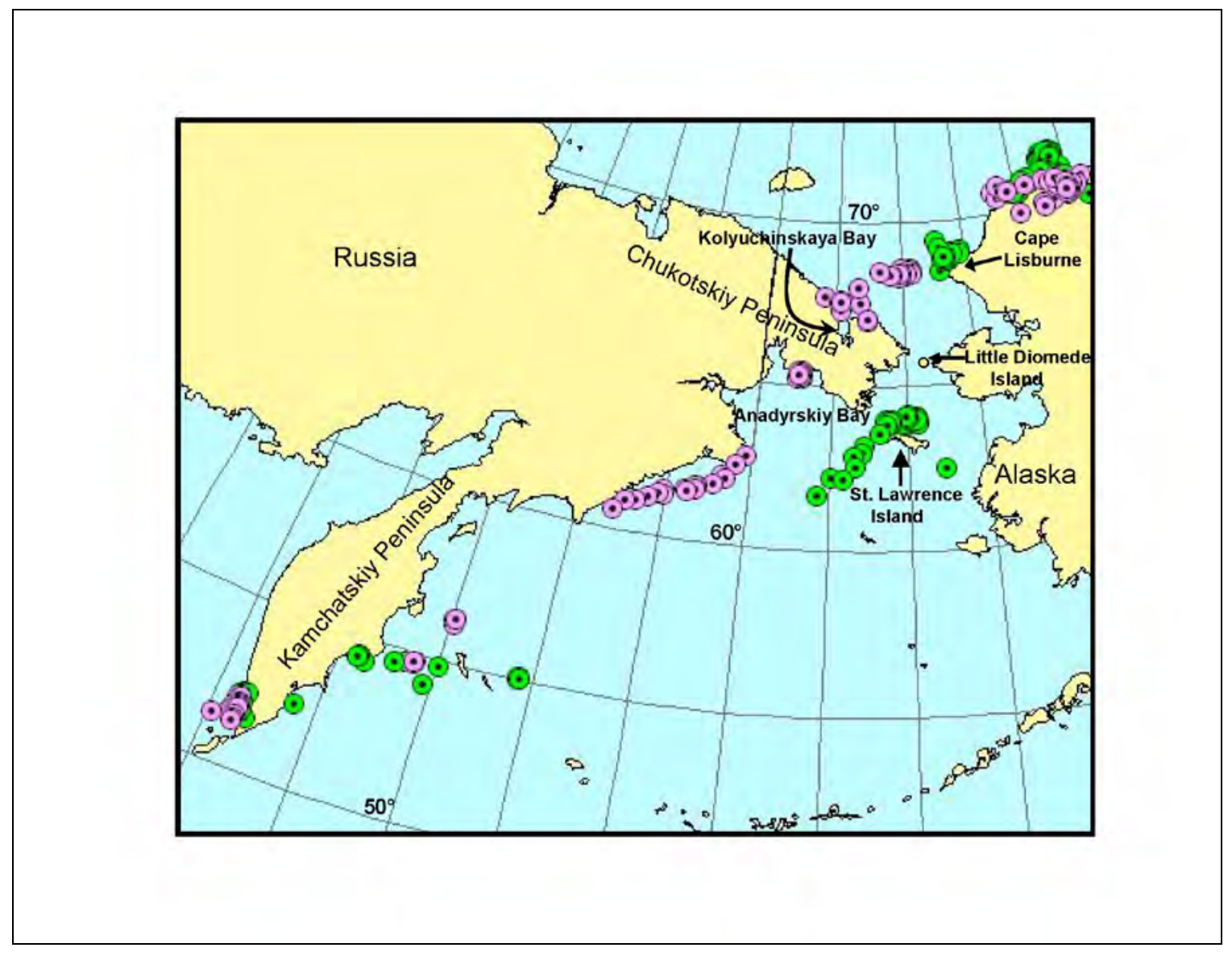

Figure 4. Fall migration of two yellow-billed loons marked in July 2003 with satellite transmitters. For both loons (\#32950 in pink, \#32951 in green), migration was progressively south and west, with nearly the entire month of September spent between $70^{\circ}$ and $60^{\circ}$ latitude. 
Table 1. Predictions of the effect of harvest on population size and trend of yellow-billed loons.

[The methods section describes the derivation of survival and reproductive data that are then input to a matrix projection model. The harvest numbers of 45, 317, and 1,077 reflect estimates of annual harvest of yellow-billed loons in the Bering Strait region in three different years (Naves, 2008). Each cell contains three non-italicized numbers: first is annual population growth rate, given the indicated harvest and the population to which that harvest is allocated; second is the number of years from present until the population falls below half of current size; and the third number is population size after three generations (18 years per generation $=54$ years). Initial population size is given in the "Reference Population" column. This model assumes hunting mortality is additive and not compensatory. The mortality rate, rather than mortality number, from harvest is kept constant across the years of each population projection. Thus, initial harvest number (for example, 45,317 , or 1,077) divided by the starting population size equals the mortality rate that is then projected over time. The italicized number in the first data column equates to the harvest amount that would result in a mortality rate that produces the population trend currently observed in northern Alaska]

\begin{tabular}{|c|c|c|c|c|c|c|c|}
\hline \multirow{4}{*}{$\begin{array}{l}\text { Reference } \\
\text { Population }\end{array}$} & \multicolumn{7}{|c|}{ Amount of annual harvest of Yellow-billed Loons } \\
\hline & \multicolumn{5}{|c|}{ Proportionately allocated among age classes } & \multirow{2}{*}{\multicolumn{2}{|c|}{$\begin{array}{c}\text { Disproportionately allocated among age classes } \\
\text { Harvest constant from year to year }\end{array}$}} \\
\hline & \multicolumn{4}{|c|}{ Harvest constant from year to year } & \multirow{2}{*}{$\begin{array}{c}\text { Harvest varies among years } \\
\text { Varies among years similar to } \\
\text { the } 2004-07 \text { reported pattern: } \\
45,317 \text {, and then } 1,077\end{array}$} & & \\
\hline & $\begin{array}{l}\text { Harvest number } \\
\text { to attain } \\
\text { current trend }\end{array}$ & 45 & 317 & 1,077 & & $\begin{array}{c}\text { Allocated harvest of } 317 \\
\text { to loons 2-yrs old and } \\
\text { younger }\end{array}$ & $\begin{array}{l}\text { Allocated harvest of } \\
317 \text { to loons 3-yrs } \\
\text { old and older }\end{array}$ \\
\hline Alaska & ${ }^{1} 52$ & & & & & & \\
\hline$(\mathrm{N}=4,508)$ & & 0.99007 & 0.9297 & 0.7611 & 0.8937 & 0.9500 & 0.9123 \\
\hline & & 0 & 10 & 3 & 6 & 13 & 9 \\
\hline & & 2,629 & 88 & 0 & 7 & 274 & 23 \\
\hline Alaska + & & 0.9957 & 0.9695 & 0.8962 & 0.9538 & 0.9754 & 0.9615 \\
\hline Chukotka & & 162 & 23 & 7 & 15 & 28 & 18 \\
\hline$(\mathrm{N}=10,372)$ & & 8,222 & 1,945 & 28 & 764 & 2,673 & 1,182 \\
\hline Minimum & & 0.9976 & 0.9832 & 0.9426 & 0.9745 & 0.9860 & 0.9786 \\
\hline Global & & 295 & 41 & 12 & 27 & 50 & 33 \\
\hline$(\mathrm{N}=18,764)$ & & 16,523 & 7,496 & 773 & 4,575 & 8,703 & 5,772 \\
\hline Maximum & & 0.9988 & 0.9916 & 0.9713 & 0.9873 & 0.9929 & 0.9893 \\
\hline Global & & 601 & 83 & 24 & 54 & 97 & 66 \\
\hline$(\mathrm{N}=37,528)$ & & 35,261 & 23,795 & 7,808 & 18,712 & 25,454 & 20,964 \\
\hline
\end{tabular}

${ }^{1}$ Population growth rate of yellow-billed loons estimated by Mallek and others (2007) for Alaska’s Arctic coastal plain. 


\title{
Appendix 1. SAS Code Used for Performing Matrix Projections to Model Effects of Harvest on Yellow-Billed Loon Populations.
}

\author{
data YBLOs; \\ Harvest=1077; * number harvested in 1st year, thereafter a constant mortality rate due \\ to harvest is maintained as based on the Harvest/startpop ratio; \\ * Entering 0 for harvest gives the initial stable population; \\ startpop=4508; * starting population size; \\ MortType=2; \\ * $0=$ No harvest; \\ * $1=$ Harvest on YOY and 1 and 2 year old birds; \\ * 2=Proportional harvest across age classes; \\ * 3=Harvest on 3 yr and older birds; \\ Rotate='No'; * If 'Yes', cycle between the 3 harvest levels (45, 317, and 1077); \\ * COLO survival of 0.91 adjusted, in concert with other S rates, to yield stable pop; \\ Surv_ad=0.928018; \\ * COLO survival of 0.80 adjusted and really reflects survival from 1-yr to 2-yr old; \\ Surv_2yr=0.81584; \\ * as above and really reflects survival from fledge to 1-yr old; \\ Surv_1yr=0.7*1.0198; \\ * mean annual production rate of female chicks, from 13 years of ABR data at the Colville; \\ prod $=0.284615^{*} 1.172 / 2$; \\ * fertility rate of age class 6 , which includes the adjusted survival from fledge to 1-year of age; \\ f6=prod*0.7*1.0198; \\ * Initial age structure percents, as derived from a starting matrix model of the above vital rates; \\ age $1=0.0811 ; * 1$-yr olds; \\ age2 $=0.0662 ; * 2$-yr olds; \\ age $3=0.0614 ; * 3$-yr olds; \\ age4=0.0570; * 4-yr olds; \\ age $5=0.0529 ; * 5$-yr olds; \\ age6plus $=0.6814$; * 6+-yr olds; \\ * Numerical age structure for starting pop; \\ tempage $1=$ age $1 *$ startpop; \\ tempage $2=$ age $2 *$ startpop; \\ tempage $3=$ age $3 *$ startpop; \\ tempage4=age4*startpop; \\ tempage $5=$ age $5 *$ startpop; \\ tempage6=age6plus*startpop; \\ oldpop=tempage3+tempage4+tempage5+tempage6; \\ youngpop=tempage $1+$ tempage $2+$ tempage $6 *$ f6;
}


countit $=0$;

* project far enough to witness halving of the populations for all scenarios;

do year=2008 to 2920;

countit=countit +1 ;

temppop=tempage1+tempage2+tempage3+tempage4+tempage5+tempage6;

temppopa=tempage3+tempage4+tempage5+tempage6; * older age classes;

* fertility rates for ages 1 to 5, with the COLO based assumption that all YBLOs begin breeding at age 6;

$\mathrm{f} 1=0 ; \mathrm{f} 2=0 ; \mathrm{f} 3=0 ; \mathrm{f} 4=0 ; \mathrm{f} 5=0$;

*projects population size, by age class, for the next year, where harvest is focused on juvenile birds;

if Rotate='Yes' then do; * the counter allows harvest rate to rotate among years;

if countit $=1$ then Harvest $=45$;

if countit $=2$ then Harvest $=317$;

if countit=3 then Harvest=1077;

end;

if countit $=3$ then countit $=0$;

* brute force multiplication of a Leslie matrix of vital rates with a vector of age class

abundances, to project to the next year's abundance, in the absence of harvest;

* A pre-breeding census is used for matrix formulation, as population counts are done in early summer;

* situation of no harvest - simply projecting the starting matrix;

if MortType $=0$ then newtemp1=tempage $6 *$ f6;

if MortType $=0$ then newtemp2=tempage $1 *$ Surv_2yr;

if MortType $=0$ then newtemp3=tempage2*Surv_ad;

if MortType $=0$ then newtemp4=tempage3*Surv_ad;

if MortType $=0$ then newtemp5=tempage $4 *$ Surv_ad;

if MortType $=0$ then newtemp6=tempage5*Surv_ad+tempage6*Surv_ad;

* Projecting forward the population at the next time step, with all harvest on younger birds;

if MortType=1 then newtemp1=tempage6*prod*Surv_1yr*(1-Harvest/(youngpop*Surv_1yr));

if MortType $=1$ then newtemp2=tempage $1 *$ Surv_2yr*(1-Harvest/(youngpop*Surv_2yr));

if MortType=1 then newtemp3=tempage2*Surv_ad*(1-Harvest/(youngpop*Surv_ad));

if MortType $=1$ then newtemp4=tempage3*Surv_ad;

if MortType $=1$ then newtemp5=tempage4*Surv_ad;

if MortType=1 then newtemp6=tempage5*Surv_ad+tempage6*(Surv_ad);

* Projecting forward with harvest on all age classes;

if MortType=2 then newtemp1=tempage6*prod*Surv_1yr*(1-Harvest/startpop);

if MortType $=2$ then newtemp2=tempage $1 *$ Surv_2yr*(1-Harvest/startpop);

if MortType=2 then newtemp3=tempage2*Surv_ad*(1-Harvest/startpop);

if MortType=2 then newtemp4=tempage $3 *$ Surv_ad*(1-Harvest/startpop);

if MortType=2 then newtemp5=tempage4*Surv_ad*(1-Harvest/startpop); 
if MortType=2 then newtemp6=tempage5*Surv_ad*(1-Harvest/startpop)+tempage6*Surv_ad*(1Harvest/startpop);

* Projecting forward with harvest on older birds;

if MortType=3 then newtemp1=(tempage6*(prod)*Surv_1yr);

if MortType=3 then newtemp2=tempage1*(Surv_2yr);

if MortType $=3$ then newtemp3=tempage $2 *($ Surv_ad);

if MortType=3 then newtemp4=tempage3*Surv_ad*(1-Harvest/(oldpop*Surv_ad));

if MortType=3 then newtemp5=tempage4*Surv_ad*(1-Harvest/(oldpop*Surv_ad));

if MortType $=3$ then newtemp6=tempage $5 *$ Surv_ad* $(1-$

Harvest/(oldpop*Surv_ad))+tempage6*Surv_ad*(1-Harvest/(oldpop*Surv_ad));

if newtemp $1<0$ then newtemp $1=0$; if newtemp $2<0$ then newtemp $2=0$;

if newtemp $3<0$ then newtemp $3=0$; if newtemp $4<0$ then newtemp $4=0$;

if newtemp $5<0$ then newtemp5 $=0$; if newtemp $6<0$ then newtemp $6=0$;

* new current population size;

newpop=newtemp1+newtemp2+newtemp3+newtemp4+newtemp5+newtemp6;

* new current population size of age 3 and up;

newpopa=newtemp3+newtemp4+newtemp5+newtemp6;

tempage1=newtemp1;

tempage2=newtemp2;

tempage $3=$ newtemp3;

tempage4=newtemp4;

tempage $5=$ newtemp5;

tempage6=newtemp6;

* growth rate for most current year;

lamda=(newpop/temppop);

* growth rate for most current year of the 3+year old birds, used to detect time lags in detecting population effects of harvest disproportionately allocated among age classes ;

lamda_A=(newpopa/temppopa);

harvnum=temppop-newpop;

mortrate=harvest/startpop;

output;

end;

proc print; var year temppop newpop harvnum mortrate newtemp1 newtemp2 newtemp3

newtemp4 newtemp5 newtemp6 lamda temppopa newpopa lamda_A;

proc means; var lamda mortrate;

run; 
Publishing support provided by the U.S. Geological Survey Publishing Network, Tacoma Publishing Service Center

For more information concerning the research in this report, contact the Director, Alaska Science Center

U.S. Geological Survey

4210 University Dr.

Anchorage, Alaska 99508-4650

http://alaska.usgs.gov 


\section{$\mathbb{E}$ 总}

as

沗

흥

ำ

웅

$\stackrel{ }{\bar{\sigma}}$

思

오

종

올

S

를

콩

욱

西

$\sum_{1}$

밀

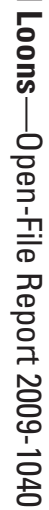

